\title{
Correction to: Unemployment in administrative data using survey data as a benchmark
}

\section{Cristina Lafuente ${ }^{1}$}

Published online: 6 June 2020

(c) The Author(s) 2020

\section{Correction to: SERIEs}

$$
\text { https://doi.org/10.1007/s13209-019-0200-1 }
$$

This document corrects 6 errors in Unemployment in administrative data using survey data as a benchmark. The errors consist of 5 superficial typographical errors and a missing footnote. These are as follows:

(1) In Section 3, "The unemployment gap", line 3 of 7th paragraph, "4 years" should read "6 years" instead.

(2) In Section 4.2, "STU expansion", line 2 of 3rd bulleted list, "4 years" should read "6 years" instead.

(3) In the first reference of "References" section, the author names should be "Arranz JM and Serrano CG (2011)"

(4) In the 14th reference of "References" section, the author names should be "Arranz JM and Serrano CG (2014)"

(5) There should be a footnote to Table 5 stating "Please note that the columns do not add to the total, since these numbers refer to the destination of completed unemployment spells, while "Total" refers to all spells, completed and uncompleted."

(6) In Section 5.4, "Alternative LFS measures", line 3, the old acronym of Instituto Nacional de Empleo, INEM, is incorrectly used as it should refer to the Servicio Público de Empleo Estatal, SEPE.

The author would like to thank Carlos García-Serrano for helpful comments.

Open Access This article is licensed under a Creative Commons Attribution 4.0 International License, which permits use, sharing, adaptation, distribution and reproduction in any medium or format, as long as you give appropriate credit to the original author(s) and the source, provide a link to the Creative Commons licence,

The original article can be found online at https://doi.org/10.1007/s13209-019-0200-1.

Cristina Lafuente

Cristina.Lafuente@ed.ac.uk

1 University of Edinburgh, Edinburgh, UK 
and indicate if changes were made. The images or other third party material in this article are included in the article's Creative Commons licence, unless indicated otherwise in a credit line to the material. If material is not included in the article's Creative Commons licence and your intended use is not permitted by statutory regulation or exceeds the permitted use, you will need to obtain permission directly from the copyright holder. To view a copy of this licence, visit http://creativecommons.org/licenses/by/4.0/.

Publisher's Note Springer Nature remains neutral with regard to jurisdictional claims in published maps and institutional affiliations. 